\title{
INTERAKSI SOSIAL ETNIS CINA-JAWA KOTA SURAKARTA
}

\author{
Verbena Ayuningsih Purbasari $^{1^{*}}$, Suhamo ${ }^{2}$
}

${ }^{1}$ Graduate Student of Civic Education, Graduate School, Universitas Negeri Yogyakarta, Indonesia

${ }^{2}$ Department of Civic Education, Graduate School, Universitas Negeri Yogyakarta, Indonesia

\begin{tabular}{l} 
ARTICLE INFORMATION \\
\hline Submitted : 25 September 2018 \\
Review : 05 April 2019 \\
Accepted : 10 May 2019 \\
Available online: June 2019 \\
KEYWORDS \\
\hline Social Interaction, Chinese Ethnicity, Javanese \\
Ethnicity, Surakarta, Conflict \\
CORRESPONDENCE \\
\hline${ }^{*}$ E-mail: verbenaayu29.2017@student.uny.ac.id \\
\hline
\end{tabular}

\section{A. PENDAhULUAN}

$\mathrm{P}$ asca reformasi tahun 1998, Indonesia mengalami gejala kuat terkait masalah etnis dan sejak itulah muncul beragam isu yang mengarah pada diskriminasi dan konflik kekerasan di Surakarta. Di Indonesia, orientasi konsep multikulturalisme ideal pasca reformasi ternyata belum mampu sepenuhnya mengakomodasi etnis keturunan Cina sebagai bagian integral dari masyarakat Indonesia (Juditha, 2015). Upaya rekonsiliasi terus menerus dilakukan untuk mengurangi gejala etnis yang semakin menguat. Hingga akhirnya pada awal abad ke-21 Masehi, terjadi proses demokratisasi yang luar biasa di Indonesia yang memberi harapan kepada masyarakat dari beragam etnis memiliki ruang dan kesempatan yang sama untuk berupaya dalam mengusahakan kehidupannya terutama dalam bidang politik. Selanjutnya, proses tersebut lambat laun membawa arah kepada tumbuhnya integrasi nasional yang diwujudkan dalam berbagai kegiatan dan budaya masyarakat (Suwirta, A \& Adam, 2012).

Konflik dan integrasi dapat diibaratkan seperti dua sisi mata uang yang tidak mudah untuk ditiadakan satu sama lain. Pasca konflik, akan muncul integrasi yang ditandai dengan

\section{A B S T R A C T}

Surakarta has a multiethnic and multicultural society. There have been long conflicts that led to forms of discrimination and violence against ethnic Chinese in Surakarta. This conflict resulted in deep trauma for the Surakarta society. Conflict reconciliation is needed so that there is no gap between the society. One of the efforts made is to carry out social interactions. The purpose of this study was to create a scheme of forms of social interaction spread across several fields. This article was prepared using a library study method where the data obtained came from various books, journals, and theses. The results show that the interaction of Chinese and Javanese in Surakarta can be made into a scheme grouped in 8 fields, such as language, education, economics, religion, community activities, arts, marriage, and culture

penataan kembali sistem-sistem sosial dalam masyarakat (Lukman, 2018). Dalam kehidungan masyarakat Indonesia, integrasi nasional merupakan bagian dari perekat bangsa. Integrasi nasional dibangun di atas kemajemukan bangsa Indonesia yang memiliki beragam subduksi kultur yang bersifat kedaerahan. Pandangan ini ditarik berdasarkan realita bahwa masyarakat Indonesia merupakan masyarakat multietnis yang lahir dalam budaya dan adat yang dilestarikan dalam kelompok etnisnya. Selain itu, latar belakang geografis Indonesia sebagai negara kepulauan turut pula menjadi sebab mengapa masyarakat Indonesia kini memiliki kultur yang beragam. Dari perbedaan kultur dan bentangan wilayah yang sangat luas inilah integrasi bangsa Indonesia terbentuk. Kuatnya ikatan sebuah integrasi tidak hanya terletak dari persamaan kegiatan dan tujuan hidup, melainkan juga pada kemampuan mengikat segala bentuk keragaman dan perbedaan yang dimiliki masyarakat.

Konsepsi yang demikian pada akhirnya melahirkan suatu persoalan tersendiri bagi bangsa Indonesia. Sebab di tengah-tengah masyarakat Indonesia yang multietnis, akan selalu muncul stereotip negatif terhadap etnis yang dikhawatirkan mengganggu jalannya proses integrasi. Salah satu wilayah di Indonesia yang memiliki permasalahan demikian adalah Kota 
Surakarta. Kota yang terletak di Provinsi Jawa Tengah ini merupakan kota multikultur dan telah lama menjadi tempat huni bagi berbagai macam etnis dan suku, salah satunya adalah etnis Cina yang memiliki jumlah penduduk cukup banyak untuk ukuran etnis minoritas. Kota Surakarta memiliki sejarah panjang terkait konflik etnis Cina-Jawa terutama sejak terjadinya peristiwa Geger Pecinan pada tahun 1740-an yang menewaskan kurang lebih 10.000 orang Tionghoa dan tragedi kerusuhan bulan Mei 1998 di mana orang Tionghoa mengalami kerugian besar baik secara fisik, moral, dan materi. Konflik tersebut kemudian menyisakan stereotip negatif terhadap etnis Cina sebagai akibat dari perilaku dan gagasan yang cenderung kontradiktif antara etnis Cina dan Jawa di Surakarta (Baidhawy, 2019).

Beberapa tahun setelah peristiwa itu berlalu, muncullah upaya menyusun solusi-solusi alternatif bagi etnis Cina-Jawa untuk meredam segala akibat dari konflik yang berkepanjangan. Dengan semangat Bhinneka Tunggal Ika, kini bangsa Indonesia telah bangkit dan tumbuh di tengah ancaman dan tantangan yang lebih kuat dibandingkan masa sebelumnya (Ahimsa-Putra, 2014). Solusi dituangkan dalam bentuk interaksi sosial yang meliputi berbagai bidang. Interaksi sosial sebuah proses sosial yang dilakukan oleh setiap individu sebagai anggota dari suatu masyarakat (Suseno, 2017).

Etnis Cina di Surakarta telah lama hidup berdampingan dengan penduduk pribumi Jawa dalam waktu yang lama. Tentu akan dijumpai beragam bentuk interaksi sosial dalam lingkungan masyarakat tersebut. Interaksi sosial masyarakat akan sulit untuk dipahami dan dimaknai apabila tidak dikelompokkan dengan menggunakan skema tertentu. Oleh karena itu, tujuan penulisan artikel ini adalah untuk mengetahui bagaimana interaksi yang terbentuk antara etnis Cina dan Jawa di Surakarta yang dilihat melalui bidang pendidikan, bahasa, ekonomi, agama, kegiatan masyarakat, kesenian, perkawinan, dan kebudayaan.

\section{B. METODE PENELITIAN}

$\mathrm{M}$ etode yang digunakan dalam penulisan artikel ini adalah studi kepustakaan (library research) yaitu metode pengumpulan data melalui telaah terhadap sumber-sumber kepustakaan(Mahmud, 2011)yang dilakukan dengan cara mengolah data yang berasal dari buku, jurnal, skripsi, maupun tesis yang berhubungan dengan interaksi sosial etnis Arab dan Jawa di Surakarta. Setelah diolah, kemudian data dianalisis, dirangkum, dan digeneralisasikan dengan menggunakan kajian teori yang relevan sehingga menjadi satu kesatuan artikel yang utuh.

\section{HASIL DAN PEMBAHASAN}

$\mathrm{K}$ onsep zoon politicon nampaknya telah mendarah daging menjadi sebuah prinsip dalam kehidupan manusia. Tidak ada satupun individu yang dengan kekuatannya mampu hidup sendiri tanpa bergantung kepada orang lain. Kehidupan sosial dibangun melalui interaksi dan kerjasama individu maupun kelompok untuk mewujudkan tujuan bersama. Interaksi dalam satu sisi merupakan jalan bagi masyarakat untuk membentuk sistem sosial dan di sisi lain memberi kewajiban kepada individu dan kelompok untuk memelihara dan mempertahankan bentuk komunikasi dan relasi yang telah dijalani.

Pada dasarnya masyarakat memiliki dua pengertian besar. Pertama, masyarakat adalah sebuah realitas yang dapat muncul dengan sendirinya. Kedua, masyarakat sebagai sebuah realitas yang terbentuk terlebih dahulu karena adanya interaksi dan komunikasi antar individu (Plummer, 2011). Dikotomi pengertian ini mendorong lahirnya dua aliran pemikiran yang berbeda mengenai hakikat dan asal muasal masyarakat. Namun apabila dicermati secara mendalam, kedua pengertian tersebut merupakan satu kesatuan yang kebenarannya dapat ditarik dari kedua sisi, baik dari pengertian pertama maupun pengertian kedua.

Hal yang dapat dimengerti dari pengertian pertama ialah, masyarakat dapat terbentuk dengan sendirinya tanpa melalui suatu proses dan sebab. Pengertian ini memberi indikasi bahwa masyarakat secara serta merta terbentuk dari kumpulan individu yang memiliki homogenitas dalam berbagai hal, kegiatan, bahkan tujuan. Sehingga mereka tidak perlu lagi mengambil waktu yang lama untuk menyesuaikan diri karena telah menemukan kecocokan satu sama lain. Pengertian kedua, merujuk pada hakikat masyarakat yang terbentuk sebagai hasil interaksi dan komunikasi yang telah ada terlebih dahulu. Dalam komunitas, setiap individu memiliki kepentingan yang akan bersinggungan dengan kepentingan individu lain. Agar perbedaan itu terorganisir dengan baik dan setiap individu mendapat hak pemenuhan kepentingannya, maka individu satu sama lain saling berinteraksi dan melakukan komunikasi. Dalam proses interaksi dan komunikasi itulah individu saling memiliki rasa ketergantungan dengan yang lain hingga pada akhirnya terbentuklah masyarakat.

Sebagai sebuah komunitas resmi, masyarakat Indonesia tidak lepas dari ciri kemajemukan dan pluralisme budaya. Jenis budaya terbentuk berdasarkan interaksi-interaksi anggota masyarakat dalam kehidupan seharihari. Setiap daerah di Indonesia memiliki ciri khas budaya masing-masing. Budaya daerah dapat berasal dari nilai-nilai lokal yang ada di daerah 
tertentu di Indonesia. Tetapi ada juga budaya yang dibawa oleh etnis-etnis pendatang dari luar negara Indonesia yang tinggal menetap dan berinteraksi di Indonesia kemudian membentuk budaya campuran dengan penduduk pribumi.

\section{Surakarta sebagai Kota Multietnis Multikultur}

Masyarakat Kota Surakarta adalah masyarakat multietnis. Selain dihuni oleh mayoritas etnis Jawa, Kota Surakarta selebihnya juga dihuni oleh etnis minoritas seperti etnis Arab dan Cina.Etnis-etnis tersebut ditempatkan di wilayah secara tersendiri di Surakarta. Sebagai contoh, Kampung Pecinan merupakan daerah untuk menempatkan orang Cina beserta keturunannya,begitu juga Kampung Arab sebagai daerah tempat tinggal tinggal bagi orang-orang Arab dan keturunannya. Kedua etnis ini tinggal secara berkelompok dan ditempatkan dalam wilayah khusus di Surakarta agar lebih mudah bagi kedua etnis tersebut berkomunikasi dalam kelompok etnisnya. Walaupun demikian, dalam kehidupan sehari-hari etnis-etnis ini tetap berinteraksi dengan penduduk pribumi yang mayoritas merupakan orang Jawa. Keberadaan etnis-etnis ini juga membawa pengaruh penting dan positif bagi masyarakat asli Kota Surakarta dan sekitarnya, sebab banyak sekali kontribusi yang diberikan antara lain mencakup segi agama, ekonomi, pendidikan, budaya, politik maupun organisasi sosial.

Pada dasarnya, etnis ialah sebuah kata yang berasal dari bahasa Yunani Kuno yaitu etnos yang mengarah pada sebuah konsep manusia yang beradab. Sedangkan dalam Kamus Besar Bahasa Indonesia (Balai Pengembangan dan Pembinaan Bahasa, 2016) etnis merujuk pada komunitas sosial dalam sistem sosial/kebudayaan yang memiliki arti maupun kedudukan tertentu karena adanya keturunan, adat, agama, bahasa, dan lain-lain. Pengertian ini secara tidak langsung mengidentifikasikan faktor keberagaman yang dimiliki oleh suatu etnis. Oleh karena itu, antara etnis satu dengan yang lain dapat dibedakan dengan jelas berdasarkan pada faktor keturunan, adat yang dimiliki, agama atau kepercayaan yang dianut, maupun bahasa yang digunakan dalam berkomunikasi sehari-hari.

Selain sebagai kota multietnis, Surakarta juga merupakan kota multikultur. Disebut demikian sebab keanekaragaman budaya yang dimiliki oleh suatu masyarakat dapat terbentuk karena komposisi masyarakat tersebut terdiri dari beberapa etnis yang berbeda. Sebagai sebuah perkumpulan hidup manusia, anggota-anggota dalam masyarakat multikultur di Surakarta memiliki karakteristik yang sama dalam segi budaya dan mereka bertindak berdasarkan pada pola-pola yang sama. Terkadang budaya yang dimiliki oleh setiap etnis tidak hanya satu, sedangkan etnis yang bermukim di Surakarta ada beberapa jumlahnya. Dengan jumlah etnis dan budaya-budaya yang dimiliki oleh masingmasing etnis maka akan diperoleh akumulasi kebudayaan yang banyak jumlahnya. Hal inilah damm melatarbelakangi mengapa Kota Surakarta disebut sebagai kota multikultur.

Sebagai kota multikultur, Surakarta tentu kental sekali dengan ciri multikulturalisme.. Multikulturalisme ditandai dengan adanya integrasi dalam masyarakat dimana pemerintah setempat tidak hanya berupaya untuk mendorong penyatuan masyarakat akan tetapi juga memfasilitasi para imigran atau kaum minoritas dalam hal jaminan terhadap bahasa dan tradisi kebudayaan aslinya (Richards, 2014). Surakarta merupakan kota yang terbuka dengan etnis-etnis pendatang. Maka tidak heran apabila berkunjung di kota ini akan banyak sekali dijumpai kebudayaan-kebudayaan yang beragam. Sebagai masyarakat yang memiliki keragaman sosial, kelompok etnis, budaya, agama, aspirasi politik, dan lain-lain, masyarakat kota Surakarta secara sederhana dapat disebut sebagai masyarakat multikultural. Multikulturalisme di sini tidak hanya dipahami dengan persamaan konsep keanekaragaman etnis atau kebudayaan yang menjadi ciri masyarakat majemuk. Akan tetapi, penekanan multikulturalisme terletak pada keanekaragaman budaya dalam kesederajatan(Dewantara, 2015).

Gunawan \& Rante (2011)menjelaskan bahwa konsep masyarakat multikultural memiliki beberapa pengertian. Pertama, adanya pengakuan terhadap perbedaan dan kompleksitas kehidupan dalam bermasyarakat. Pengertian pertama ini sangat jelas karena masyarakat kota Surakarta sangat terbuka dan menghargai adanya perbedaan dan keanekaragaman dalam struktur masyarakatnya. Tidak dapat dipungkiri bahwa dalam hidup bermasyarakat sering ditemui kepentingan-kepentingan individu yang berbeda-beda dan terkadang saling berseberangan. Selain itu, hidup bermasyarakat memberi kesadaran bahwa ada banyak kepentingan yang harus dilindungi dan dihormati. Kedua, perlakuan sama terhadap berbagai komunitas dan budaya (minoritas dan mayoritas. Dalam suatu kelompok sosial atau masyarakat kota Surakarta, anggota-anggotanya berasal dari berbagai komunitas yang membawa budayanya masing-masing. Dalam konsep masyarakat multikultural, mereka saling berinteraksi dengan memberi perlakuan yang sama walaupun memiliki budaya yang berbeda-beda. Masyarakat hidup membaur dalam lingkungan dimana mereka merasa sebagai satu kesatuan masyarakat Surakarta.Ketiga, adanya kesederajatan kedudukan dalam keanekaragaman dan perbedaan. Masyarakat multikultural kota Surakarta menjunjung tinggi kesederajatan 
dalam berbagai perbedaan kebudayaan dalam lingkungan hidupnya. Tidak ada individu maupun golongan yang dianggap lebih tinggi maupun lebih rendah meskipun mereka terdiri dari beragam etnis berbeda. Masyarakat Jawa sebagai etnis pribumi memiliki rasa toleransi tinggi sehingga etnis-etnis lain yang berada di Surakarta merasa dihargai bukan sebagai tnis pendatang lagi melainkan sebagai bagian dari kesatuan masyarakat Surakarta. Sejalan dengan karakteristik yang keempat bahwa kesederajatan diikuti dengan adanya penghormatan terhadap perbedaan yang ada serta penghargaan yang tinggi terhadap hak-hak asasi manusia. Karakteristik ini diwujudkan oleh masyarakat kota Surakarta dengan saling menunjukkan rasa penghormatan dan toleransi saat perayaan harihari besar agama tertentu dan mereka menjunjung tinggi etnis lain dalam menjalankan ibadah maupun kegiatan yang berkaitan dengan tradisi budaya yang dimiliki oleh etnis-etnis di sana.Kelima, masyarakat multikultural identik dengan beberapa unsur, seperti: rasa kebersamaan, kerja sama, dan hidup damai berdampingan walaupun memiliki perbedaan. Interaksi masyarakat kota Surakarta dalam kehidupan sehari-hari tentu akan memunculkan rasa kebersamaan yang tinggi yang kemudian menumbuhkan rasa keterikatan satu sama lain. Keterikatan ini diwujudkan oleh masyarakat Surakarta dengan melakukan kerjasama dalam berbagai bidang kehidupan.

Masyarakat multikultural Surakarta didukung oleh beraneka ragam kebudayaan yang berasal dari berbagai etnis yang menempati kota tersebut. Dilihat dari asalnya, maka etnis-etnis yang terdapat di Surakarta dapat dibagi menjadi dua jenis, yakni etnis yang berasal dari dalam wilayah Indonesia dan luar wilayah Indonesia. Etnis yang berasal dari dalam wilayah Indonesia pada umumnya memiliki kebudayaan yang mengandung nilai-nilai ke-Indonesiaan, sedangkan etnis yang berasal dari luar wilayah Indonesia sangat memungkinkan masih menjaga budaya asli yang dibawa dari negara asal. Sebagai etnis yang berasal dari luar wilayah Indonesia, etnis Arab dan Cina di Surakarta dapat hidup berdampingan dengan etnis Jawa dengan cara membentuk suatu komunitas etnis secara tersendiri. Sebuah kelompok sosial dapat dikatakan sebagai komunitas etnis apabila kelompok tersebut memiliki beberapa ciri sebagai berikut (Liliweri, 2018):
a. Mampu berkembang biak secara biologis dan bertahan
b. Adanya kesamaan nilai-nilai budaya
c. Memiliki kesadaran terhadap rasa kebersa- maan dalam bentuk budaya
d. Memiliki jaringan komunikasi dan cara interaksi sendiri

e. Memiliki ciri kelompok sendiri yang dapat diterima dan dibedakan dengan ciri yang dimiliki olehkelompok lain.

Etnis dan budaya memiliki keterkaitan yang erat. Budaya terbentuk sebagai hasil dari interaksi yang dilakukan oleh masyarakat maupun komunitas sosial dalam suatu etnis. Adakalanya budaya yang terbentuk menjadi ciri khas dari keberadaan etnis tertentu. Masyarakat maupun kebudayaan memiliki sifat yang koheren satu sama lain. Hal ini dikarenakan kebudayaan selalu mengikuti di mana masyarakat berada. Kebudayaan merupakan hasil ciptaan masyarakat melalui pergaulan dan interaksi dengan menggunakan sarana dan prasarana serta potensi-potensi yang dimiliki (Wattimena, 2010).

Keberadaan berbagai macam etnis di Surakarta merupakan kajian yang menarik untuk dibahas. Terlepas dari sejarah panjang perjalanan etnis-etnis tersebut ke Indonesia, yang harus menjadi perhatian ialah pada bentuk interaksi dan komunikasi yang digunakan etnisetnis tersebut dalam membangun relasi dengan penduduk pribumi. Komunikasi merupakan kegiatan saling mengirim dan menerima pesan/informasi antara dua orang atau lebih sehingga dapat dipahami maksud dan tujuan yang ingin dicapai. Komunikasi dapat dijumpai dalam segala jenis aktifitas pada lintas waktu, tempat, dan kesempatan. Dalam kehidupan sehari-hari, komunikasi diperlukan oleh masyarakat dalam membangun relasi antar individu maupun kelompok sosial. Komunikasi sangat penting untuk mengeliminir segala jenis stereotip buruk dalam menyikapi perbedaan yang dilatarbelakangi oleh beragamnya budaya, ciri fisik, agama, bahasa, dan lain sebagainya yang dimiliki oleh masyarakat.

Persoalan komunikasi kerap muncul pada masyarakat multietnis dan multikultur. Untuk mewujudkan sebuah harmoni sosial, komunikasi perlu dibangun untuk menjaga agar masyarakat memiliki relasi yang kuat dan seimbang. Sebab, suatu relasi bergantung pada cara-cara yang digunakan oleh anggota masyarakat dalam berkomunikasi dan tingkat keberhasilan komunikasi akan menentukan seperti apa bentuk relasi yang akan dijalani.

Komunikasi dalam masyarakat multikultural setidaknya memiliki dua aspek. Pertama, menyinggung cara yang digunakan budaya dalam berkomunkasi dengan penggunaan caracara tertentu sehingga makna dan tujuan dalam komunikasi dapat ditemukan di waktu tertentu, tempat, dan lingkungan sosial. Hal ini berarti komunikasi budaya merupakan perilaku komunikatif yang ditanamkan oleh budaya tertentu. Kedua, komunikasi berperan dalam menunjukkan budaya beserta fungsi dan cara kerjanya dalam menyusun kehidupan komunal dari masyarakat dan dalam memberikan individu 
kesempatan untuk berpartisipasi, mengindentifikasi, dan menegosiasikan kehidupan tersebut. Jadi, dapat dikatakan bahwa komunikasi budaya merupakan kegiatan yang dilakukan oleh individu maupun kelompok sosial sebagai bentuk adanya tuntutan berkomunikasi dalam kehidupan mereka di dunia.

\section{Interaksi Etnis Cina dan Jawa di Surakarta}

Etnis Cina dan keturunannya di Kota Surakarta mayoritas tinggal menetap secara berkelompok di sekitaran Pasar Gede dan Kampung Balong, Kelurahan Sudiroprajan, Kecamatan Jebres. Namun semenjak tahun 1919, etnis Cina mulai tinggal secara menyebar di seluruh wilayah Surakarta dan menempati wilayah-wilayah strategis untuk memudahkan dalam berdagang. Selama ratusan tahun, etnis Cina bermukim di Surakarta dengan penduduk pribumi yang didominasi oleh orang Jawa. Berbagai sentimen dan konflik etnisitas muncul di permukaan, namun pada masa sekarang sudah jarang ditemukan permasalahan dalam relasi etnis tersebut. Upaya rekonsiliasi dan integrasi terus menerus dilakukan demi menjaga kedamaian hubungan yang telah terbentuk antara etnis Cina dan Jawa di Surakarta. Upaya tersebut diwujudkan dengan melakukan interaksi yang mencakup berbagai aspek kehidupan masyarakat.

Interaksi sosial merupakan hubungan yang bersifat timbal balik yang terjalin antara individu dengan individu, individu dengan kelompok, dan kelompok dengan kelompok (Soekanto, 2010). Interaksi tergantung pada cara yang digunakan oleh individu maupun kelompok dalam menyikapi berbagai fenomena yang terdapat di dalam masyarakat. Sering kali, fenomena-fenomena lahir sebagai akibat pengaruh sosial budaya yang terurai berdasarkan letak geografis, etnis atau kesukuan, agama atau keyakinan maupun ciri fisik. Fenomena dapat mengarah kepada indikasi disintegrasi apabila proses interaksi masyarakat terjalin dengan buruk. Namun, juga dapat memperkuat integrasi apabila proses interaksi masyarakat berlangsung dengan baik. Oleh karena itu, bentuk interaksi masyarakat etnis Cina dan Jawa menjadi titik tumpu bagi masyarakat Surakarta dalam merekonsiliasi akibat konflik masa lalu sekaligus menyaring berbagai fenomena yang terjadi sekaligus menjadi ciri khusus yang membedakan masyarakat tersebut dengan masyarakat lain. Interaksi diperlukan untuk mengurangi kesenjangan dalam masyarakat sekaligus untuk mencapai kesepemahaman dan pengakuan terhadap keberadaan suatu budaya (Muslim, 2013).

Interaksi sosial mengharuskan manusia sebagai bagian dari masyarakat untuk bekerja sama mengatur tingkah laku mereka (Misyak, Melkonyan, Zeitoun \& Chater, 2014). Aturan tingkah laku dapat bersumber dari peraturan tertulis maupun peraturan tidak tertulis yang biasanya berbentuk norma sosial yang nilainilainya telah disepakati bersama. Melalui aturan atau norma sosial tersebut, masyarakat dapat mengetahui apa yang seharusnya mereka lakukan, apa yang mereka butuhkan, apa yang akan mereka dapatkan, dan lain-lain. Interaksi sosial merupakan serapan dari multikulturalisme yang mencakup berbagai segi kehidupan sosial masyarakat.

Interaksi sosial yang terbentuk antara etnis Cina dan Jawa kota Surakarta sangatlah beragam. Oleh karena itu, interaksi perlu untuk dipetakan dalam sebuah skema agar mudah untuk dipahami. Interaksi sosial etnis Cina dan Jawa kota Surakarta dapat dilihat dalam skema berikut ini. 


\section{Skema 1. Interaksi Sosial Etnis Cina-Jawa Surakarta}

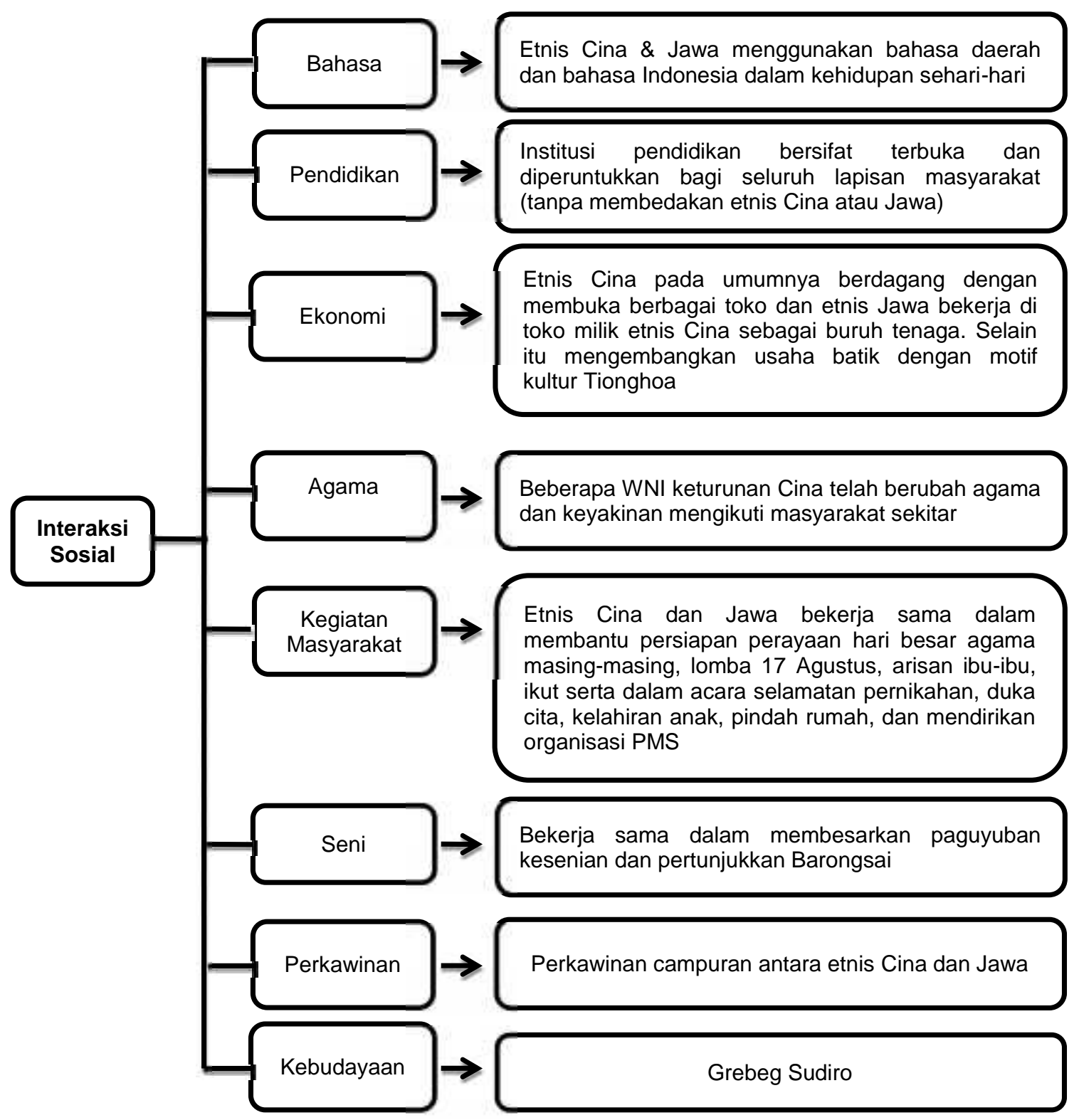

Sumber: diolah dari berbagai sumber (Aksan \& Rochayanti, 2009; Mardhan, 2014; Wahyuni \& Pelu, 2016).

Bentuk interaksi etnis Cina dan Jawa di Surakarta dapat dikelompokkan ke dalam delapan aspek/bidang, yakni: bahasa, pendidikan, ekonomi, keagamaan, kegiatan masyarakat, kesenian, perkawinan, dan kebudayaan. Adapun uraiannya adalah sebagai berikut.

\section{a. Bahasa}

Bahasa merupakan bentuk dari komunikasi verbal yang digunakan untuk menyampaikan keinginan dan tujuan memelihara budaya, memenuhi kebutuhan individu, maupun kebutuhan sosial (Lubis, 2012). Dalam kehidupan sehari-hari, masyarakat etnis Cina dan Jawa melakukan komunikasi dengan menggunakan bahasa daerah dan bahasa Indonesia. Bahasa daerah yang digunakan adalah bahasa Jawa Ngoko dan Krama. Bahasa Ngoko (Lugu) merupakan bahasa yang sering dipakai untuk berkomunikasi dengan teman sebaya, sedangkan pemakaian bahasa Krama (Alus) adalah saat berbicara dengan orang yang usianya lebih tua maupun dengan orang asing yang belum dikenal. Etnis Cina sudah jarang menggunakan bahasa Mandarin dalam percakapan sehari-hari. Mereka lebih memilih menggunakan bahasa daerah atau bahasa Indonesia supaya mudah untuk menyatu dengan orang Jawa sebagai penduduk pribumi.

\section{b. Pendidikan}

Lembaga pendidikan yang ada di kawasan Pecinan Surakarta, seperti Taman Kanak-kanak dan sekolah dasar bersifat terbuka dan diperuntukkan bagi seluruh lapisan masyarakat secara umum. Anak yang memiliki latar belakang 
Tionghoa maupun Jawa masing-masing mendapat perlakuan yang sama di sekolah. Mereka dapat bekerja sama dalam melaksanakan piket kelas, kegiatan pramuka, ekstrakurikuler, dan lain-lain. Tujuan dari institusi pendidikan tersebut adalah untuk mengarahkan pergaulan antar anak ke arah yang baik, baik etnis Cina maupun Jawa. Di sekolah, anak-anak diajarkan pendidikan multikultural supaya mereka memiliki pengertian bahwa perbedaan merupakan kekayaan bangsa Indonesia yang patut dihormati dan dijaga eksistensinya. Pendidikan multikultural menekankan berorientasi pada kegiatan dan perilaku peserta didik yang dipengaruhi oleh budayanya. Oleh karena itu setelah mendapat pendidikan multikultural, peserta didik dapat mengembangkan seluruh potensi dan kemampuan yang dimiliki sebagai pelajar dan anggota masyarakat (Wihardit, 2010).

\section{c. Ekonomi}

Dalam aspek ekonomi, etnis Cina memiliki prinsip untuk menekankan pentingnya status ekonomi mereka di tanah rantauan. Oleh karena itu, mereka merasa harus memiliki kekuatan ekonomi yang besar (Hanggara, 2016). Di Kampung Pecinan Surakarta, mayoritas etnis Cina dan keturunannya memiliki mata pencahariaan sebagai pedagang. Mereka banyak membuka toko-toko yang menjual barang kebutuhan sehari-hari, seperti toko swalayan, toko grosirataupun membuka warung makan. Toko-toko ini biasanya menjadi tujuan bagi orang Jawa yang menjadi pedagang-pedagang kecil untuk mengambil barang dan dijual kembali. Biasanya etnis Cina yang memiliki toko besar akan mempekerjakan orang Jawa sebagai buruh tenaga untuk membantu mengurus tokonya. Selain itu, bentuk lain dari interaksi etnis Cina dan Jawa dalam bidang ekonomi adalah dikembangkannya usaha batik yang mencirikan kultur Tionghoa di daerah Balong, Surakarta.

\section{d. Keagamaan}

Dalam kebudayaan, agama menjadi sumber pokok bagi nilai namun masih bersifat pasif untuk diwujudkan dalam praktek kehidupan sehari-hari. Agama memiliki ajaran-ajaran yang berperan untuk membantu proses interanalisasi nilai-nilai (BM, 2014). Agama atau keyakinan asli etnis Cina ialah Konghucu. Namun, ada beberapa WNI Cina keturunan yang memiliki kecenderungan untuk berpindah agama atau keyakinan mengikuti agama atau keyakinan penduduk sekitar, yaitu agama Islam, Kristen, Katholik, dan Budha. Dengan berpindah agama atau keyakinan, secara tidak langsung mereka mengurangi orientasi terhadap agama negeri leluhur Cina dan mulai beralih kepada kultur Indonesia. Walaupun demikian, orang Cina dan keturunan di Surakarta masih melangsungkan budaya-budaya Tionghoa, seperti Imlek, Cap Go Meh, dan lain-lain.

\section{e. Kegiatan masyarakat}

Banyak sekali kegiatan masyarakat yang dilakukan oleh etnis Cina dan Jawa dalam kehidupan sehari-sehari. Kegiatan-kegiatan yang mencerminkan bentuk interaksi kedua etnis terlihat pada saat melakukan persiapan perayaan hari besar keagamaan yang dianut oleh masingmasing etnis. Etnis Cina yang tinggal di kompleks Pecinan Surakarta tidak segan-segan untuk turut serta dalam acara selamatan bagi orang yang telah meninggal, kelahiran anak, maupun pindah rumah. Etnis Cina dan Jawa juga bekerja sama dalam melakukan beberapa kegiatan kemasyarakatan seperti mempersiapkan acara lomba dalam rangka memperingati Hari Kemerdekaan 17 Agustus 1945, arisan ibu-ibu, kerja bakti dan ronda malam yang dilakukan menurut jadwal yang telah ditetapkan. Selain itu, terdapat organisasi Perkumpulan Masyarakat Surakarta (PMS) yang didirikan oleh etnis Cina untuk mengakomodasi etnis Cina di Surakarta. Pembentukan organisasi ini juga tidak lepas dari dukungan etnis Jawa dalam melaksanakan programnya sebagai sponsor dalam berbagai kegiatan sosial di masyarakat.

\section{f. Kesenian}

"Santi Swara Laras Madya" merupakan nama sebuah paguyuban yang dibentuk oleh etnis Cina dan Jawa dalam bidang kesenian musik gamelan. Pada masa ini banyak sekali orang Cina di Surakarta yang menyukai irama musik gamelan khas Jawa. Di samping itu, interaksi dalam bidang kesenian dapat dilihat melalui pertunjukkan Barongsai, di mana pertujukkan ini rata-rata melibatkan orang Jawa sebagai pemain. Pertunjukkan seni Barongsai dibesarkan dan diurus oleh etnis Cina dan Jawa secara bersama-sama. Dalam interaksi di bidang kesenian ini terlihat bahwa etnis Cina dan Jawa saling berupaya untuk menghargai bentuk keragaman dengan sama-sama melibatkan diri melalui kegiatan seni etnis masing-masing.

\section{g. Perkawinan}

Untuk mempererat proses interaksi, etnis Cina dan Jawa Surakarta banyak yang melakukan perkawinan campuran. Dari perkawinan-perkawinan ini lahir keturunan etnis Cina dan Jawa yang disebut dengan "Ampyang". Kini, keturunan-keturunan Cina di Surakarta tidak lagi mau disebut "kowe Cina" tetapi sebagai "wong Solo". Dalam prakteknya, seringkali perkawinan campuran ini sering menimbulkan konflik dalam masyarakat, baik menyangkut kepercayaan/agama dan perbedaan budaya pada masing-masing etnis. Hal ini dikarenakan adanya culture shock percampuran dua kebudayaan yang berbeda. 


\section{h. Kebudayaan}

Kebudayaan merupakan segala sesuatu yang meliputi kegiatan dan perbuatan manusiadalam upaya mencari penyesuaian dan kesempurnaan hidup di dunia (Hun, 2011). Budaya kontemporer yang terbentuk dari interaksi etnis Cina dan Jawa di Surakarta yang menjadi magnet bagi masyarakat sekitar adalah Grebeg Sudiro. Budaya ini melambangkan perpaduan etnis Cina dan Jawa dalam rangka menyambut hari-hari khusus seperti Mulud, Syawal, Idhul Adha, dan Suro. Perayaan ini menyajikan berbagai macam hasil bumi dan makanan yang kemudian diperebutkan oleh masyarakat sekitar yang menyaksikan perayaan tersebut.

\section{KESIMPULAN}

E ksistensi etnis Cina di Surakarta turut berkontribusi dalam memperkaya keanekaragam masyarakat sekaligus menjadi bukti adanya sikap keterbukaan yang ditunjukkan oleh pemerintah setempat dalam memandang realitas multikultural masyarakat kota Surakarta. Luka trauma akibat konflik etnisitas yang melibatkan etnis Cina di masa lalu menjadi pelajaran berharga bahwa segala bentuk perbedaan sejatinya merupakan kekayaan bangsa yang patut untuk dijaga dan diberi proporsi yang tepat. Dengan semangat semboyan Bhinneka Tunggal Ika, masyarakat Surakarta bangkit membangun upaya untuk mengatasi kesenjangan dan bibit konflik yang sangat mungkin sekali dapat tumbuh di antara masyarakat. Upaya yang dapat dilakukan salah satunya ialah dengan melakukan interaksi sosial. Upaya ini merupakan langkah yang tepat karena etnis Cina dan Jawa di Surakarta dalam kehidupan sehari-hari selalu hidup berdampingan dan terlibat dalam interaksi sosial.

Etnis Cina datang dan telah ratusan tahun tinggal menetap di kota Surakarta. Oleh karena itu, banyak sekali interaksi sosial yang terbentuk di antara kedua etnis tersebut. Interaksi sosial etnis Cina dan Jawa di Surakarta yang dapat penulis identifikasi dari berbagai sumber pustaka antara lain dapat dikelompokkan ke dalam skema yang terdiri dari 8 bidang, yakni: bahasa, pendidikan, ekonomi, agama, kegiatan masyarakat, kesenian, perkawinan, dan kebudayaan. Dalam kehidupan sehari-hari, orang Cina dan keturunannya menggunakan bahasa daerah maupun bahasa Indonesia untuk berkomunikasi dengan orang lain, terutama dengan orang Jawa. Hal ini dikarenakan orang keturunan Cina sudah tidak fasih dalam menggunakan bahasa aslinya sendiri, yakni bahasa Cina. Lembaga pendidikan yang ada di Surakarta, terutama disekitar kawasan Kampung Pecinan, bersifat terbuka dan tidak memilih-milih dalam menerima peserta didik, baik dari anak keturunan Cina maupun orang Jawa. Etnis Cina di Surakarta memiliki peranan dan status ekonomi yang kuat. Hal ini terbukti dengan banyaknya pertokoan yang dimiliki oleh orang Cina. Dalam kehidupan sehari-hari, dapat dijumpai WNI keturunan Cina beberapa telah berpindah agama mengikuti agama masyarakat sekitar. Kegiatan yang sering dilakukan bersama-sama oleh etnis Cina dan Jawa ialah terlibat langsung dalam membantu persiapan perayaan hari besar agama, lomba 17 Agustus, dan kegiatan masyarakat seperti arisan, ronda malam, gotong royong, takziyah, dan lainlain. Bahkan di Surakarta didirikan sebuah organisasi PMS yang berfungsi untuk mengakomodasi seluruh kegiatan dan masyarakat khususnya etnis Cina di Surakarta. Dalam bidang seni, orang Cina dan Jawa mendirikan paguyuban kesenian "Santi Swara Laras Madya" dan terlibat dalam kesenian pertunjukkan Barongsai. Untuk mempererat interaksi antara etnis Cina dan Jawa di Surakarta, banyak dari mereka yang melakukan perkawinan campuran. Meskipun dari perkawinan tersebut memiliki kendala karena culture shock, etnis Cina dan Jawa di Surakarta tetap dapat hidup berdampingand engan damai. Sebagai puncak dari bentuk interaksi budaya, masyarakat etnis Cina dan Jawa di Surakarta memiliki budaya kontemporer yang disebut dengan Grebeg Sudiro.

\section{E. UCAPAN TERIMAKASIH}

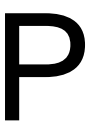
enulis ingin mengucapkan terimakasih kepada Dr. Suharno, M. Si selaku dosen pembimbing yang telah senantiasa membimbing dan mengarahkan penulis dalam menyusun artikel ini hingga terbit. Terimakasih juga penulis sampaikan kepada Program Pascasarjana Universitas Negeri Yogyakarta yang telah memberi dukungan untuk penerbitan artikel.

\section{DAFTAR PUSTAKA}

Ahimsa-Putra, H. S. (2014). Kebhinnekaan budaya sebagai modal merespons globalisasi. Literasi: Indonesian Journal of Humanities, 4(2), 167-175. Retrieved from https://jurnal.unej.ac.id/index.php/LIT/article/download/6268/4640

Aksan, E. E. \& Rochayanti, C. (2009). Komunikasi antarbudaya etnik jawa dan etnik keturunan Cina. Jurnal IImu Komunikasi, 7(1), 1-15. Retrieved from http://jurnal.upnyk.ac.id/index.php/komunikasi/article/view/6/34 
Baidhawy, Z. (2019). Dinamika radikalisme dan konflik bersentimen keagamaan di Surakarta. Journal of Social and Religious, 3(2), 43-68. https://doi.org/10.1234510/ri'ayah.v3i02.1319

Balai Pengembangan dan Pembinaan Bahasa. (2016). Kamus Besar Bahasa Indonesia (Edisi keli). Jakarta: Balai Pustaka.

BM, S. A. (2014). Konflik sosial dalam hubungan antar umat beragama. Jurnal Dakwah Tabligh, 15(2), 189-208.

Dewantara, A. . (2015). Pancasila dan multikulturalisme Indonesia. Studia Philosophica Et Theologica, 15(2), 109-126. Retrieved from http://ejournal.stftws.ac.id/studia/index.php/studia/VOL15/NO2/1

Gunawan, K. \& Rante, Y. (2011). Manajemen konflik atasi dampak masyarakat multikultural di Indonesia. Jurnal Mitra Ekonomi Dan Manajemen Bisnis, 2(2), 212-224.

Hanggara, A. (2016). Nasionalisme etnis tionghoa di Indonesia. Equilibrium: Jurnal Penelitian Pendidikan Dan Ekonomi, 14(2), 56-71. https://doi.org/10.25134/equi.v14i02.1129

Hun, K. Y. (2011). Pramoedya menggugat: melacak jejak Indonesia. Jakarta: Gramedia Pustaka Utama.

Juditha, C. (2015). Stereotip dan prasangka dalam konflik etnis tionghoa dan bugis makassar. Jurnal IImu Komunikasi, 12(1), 87-104. https://doi.org/10.24002/jik.v12i1.445

Liliweri, A. (2018). Prasangka, konflik, dan komunikasi antarbudaya. Jakarta: Kencana.

Lubis, L. A. (2012). Komunikasi antarbudaya tionghoa dan pribumi dalam penggunaan bahasa. Jurnal IImu Komunikasi, 10(3), 285-294. Retrieved from http://jurnal.upnyk.ac.id/index.php/komunikasi/article/view/46/50

Lukman. (2018). Disintegrasi sosial budaya. Risalah: Jurnal Pendidikan Dan Studi Islam, 4(2), 64-73. https://doi.org/10.5281/zenodo.1311553

Mahmud. (2011). Metode Penelitian Pendidikan. Bandung: Pustaka Setia.

Mardhan, R. (2014). Akulturasi Antar Budaya Masyarakat Etnis Tionghoa dan Jawa. Universitas Sebelas Maret.

Misyak, J.B., Melkonyan, T., Zeitoun, H., \& Chater, N. (2014). Unwritten rules: virtual bargaining underpins social interaction, culture, and society. Trends in Cognitive Sciences, 18(10), 512 519. https://doi.org/10.1016/.tics.2014.05.010

Muslim, A. (2013). Interaksi sosial dalam masyarakat multietnis. Jurnal Diskursus Islam, 1(3), 484494. Retrieved from http://journal.uinalauddin.ac.id/index.php/diskursus_islam/article/view/6642/5402

Plummer, K. (2011). Sosiologi: the basic. Jakarta: Rajawali Press.

Richards, D. P. (2014). National identity in multicultural societies: the political use of national identity in Australia (Universiteit Leiden). Retrieved from https://openaccess.leidenuniv.nl/handle/1887/26187

Soekanto, S. (2010). Sosiologi suatu pengantar. Jakarta: Rajawali Press.

Suseno, D. (2017). Komunikasi kesukubangsaan. Jurnal Antropologi: Isu-Isu Sosial Budaya, 19(1), 27-31. https://doi.org/10.25077/jantro.v19.n1.p27-31.2017

Suwirta, A \& Adam, A. (2012). Membincang kembali masalah etnisitas, nasionalitas, dan integrasi nasional di Indonesia. Atikan: Jurnal Kajian Pendidikan, 2(2), 253-272. Retrieved from http://www.journals.mindamas.com/index.php/atikan/article/view/ 135/134

Wahyuni, S. \& Pelu, M. (2016). Pasang-surut relasi tionghoa-jawa di Surakarta. Hasil Penelitian Desentralisasi Penelitian Unggulan Perguruan Tinggi.

Wattimena, L. (2010). Migrasi: etnisitas budaya sebagai identitas bangsa Indonesia. Jurnal Arkeologi Papua, 2(2), 25-35. Retrieved from https://jurnalarkeologipapua.kemdikbud.go.id/index.php/jpap/article/view/102/100

Wihardit, K. (2010). Pendidikan multikultural: suatu konsep, pendekatan dan solusi. Jurnal Pendidikan, 11(2), 96-105. Retrieved from http://jurnal.ut.ac.id/index.php/JP/article/view/98 